\title{
Chapter 5 \\ Governing for Drought and Water \\ Scarcity in the Context of Flood Disaster \\ Recovery: The Curious Case of Somerset, \\ United Kingdom
}

\author{
Alison L. Browne, Steve Dury, Cheryl de Boer, Isabelle la Jeunesse \\ and Ulf Stein
}

\subsection{Introduction to Somerset, UK: The Land of the Summer People}

Historically, flooding has dominated the physical and political landscape of Somerset, UK. Somerset has been known throughout history as 'the land of the summer people' with the floodplain only being used in the summer, due to its seasonal winter flooding. One of the unique features of this region is the Somerset Levels and Moors - a highly managed river and wetlands system, which is artificially drained and irrigated in order to open the area for productive settlement and uses such as farming. These water management systems extend back to the time of

\footnotetext{
A.L. Browne $(\bowtie)$

Geography/Sustainable Consumption Institute, University of Manchester, Rm 1.026 Level 1 Arthur Lewis Building, Manchester M139PL, UK

e-mail: alison.browne@manchester.ac.uk

S. Dury

Community Infrastructure, Somerset County Council, County Hall, PP B2E 2A, Taunton, Somerset TA14DY, UK

e-mail: sdury@somerset.gov.uk

C. de Boer

Faculty of Geoinformation Science and Earth Observation, ITC, University of Twente, Drienerweg 99, Enschede 7522ES, Netherlands

e-mail: c.deboer@utwente.nl

I. la Jeunesse

UMR CNRS CITERES, University of Tours, Maison Des Sciences de L'homme, 33 allée Ferdinand de Lesseps, 30204 Tours, France

e-mail: isabelle.lajeunesse@univ_tours.fr

U. Stein

Ecologic Institute, Pfalzburger Str. 43-44, 10717 Berlin, Germany

e-mail: ulf.stein@ecologic.eu

(C) The Author(s) 2016

H. Bressers et al. (eds.), Governance for Drought Resilience,

DOI 10.1007/978-3-319-29671-5_5
} 

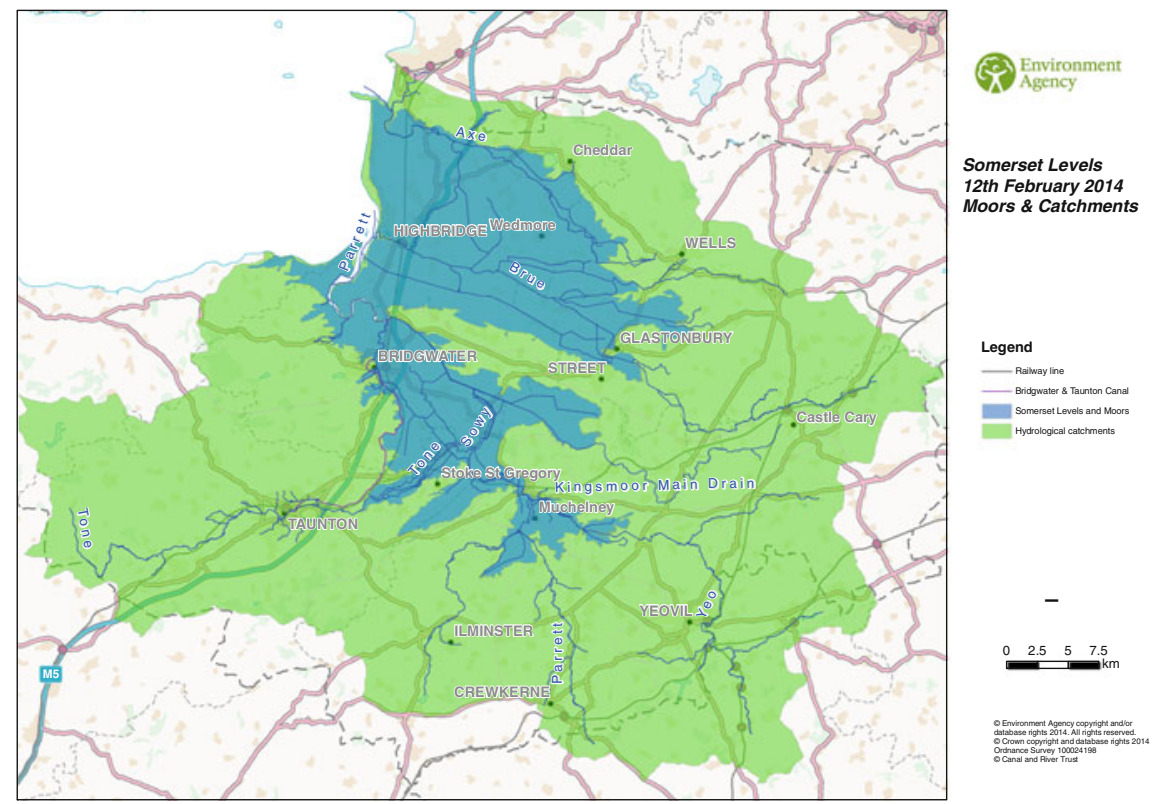

Fig. 5.1 Map of Somerset levels, moors and catchments. Environment Agency (EA) figure

the Norman Conquest (eleventh Century) for the coastal Levels, with the Moors enclosed and drained with fields, ditches, rhynes and engineered rivers between 1750 and 1850 (Clout 2014; Natural England 2013). This landscape has become one of the UK's most significant (peat) wetland natural environments, and has emerged as a result of a complex management history characterised by the coexistence of agriculture and water/environmental management (Natural England 2014). This history has created an interesting heritage of farming, wetland and natural wildlife within the landscape and $13 \%$ of this area is now recognised as a Site of Special Scientific Interest, a Special Protection Area and an internationally recognised Ramsar wetland site (Natural England 2013, 2014) (Fig. 5.1).

Flooding is still a significant agenda for the region with a series of three floods occurring between April 2012 and March 2014-with the flooding event of December 2013 to March 2014 being particularly devastating (McEwen et al. 2014; Natural England 2013; Thorne 2014). However, the area is also sensitive to drought events, having been on the precipice of an increasingly severe drought throughout 2010-2012 as was much of the UK (Lever 2012; Waterwise 2013). Given the theme of this book and the project on which it is based, this chapter focuses on the governance of drought for the Somerset region; however, the assessment and reflections are made with consideration of the broader water management history and current governance structure of the region. In fact the flooding events of 20132014 disrupted both the pilot programmes within Somerset presented in Sect. 5.3, and the governance assessment presented in Sect. 5.4. Analytically, this focus on drought in the context of flooding is necessary as recent history has shown Somerset 
is vulnerable to shifts between extreme events even within one year (e.g. in 2012 there was a shift from drought to small flood events). This chapter reflects on the governance conditions for drought following two visits to the region-one in September 2013 following the period of drought, and another again in October 2014 after a period of flooding recovery (Browne et al. 2015).

The chapter is structured as follows: Sect. 5.2 overviews the national water management and drought context; Sect. 5.3 highlights the geo-hydro context and overviews specific drought policy and measures taken in the Somerset region with the non-academic partners in the DROP project. Section 5.4 in particular captures the assessment of the governance context in Somerset. It highlights our reflections after the first visit that there were many positive elements emerging. These ranged from an increasing breadth and variety of instruments and measures used to plan for drought; increasing number of relationships being built to deal with policies and on-the-ground measures for drought; and increasing visibility of the issue of drought for the region after a period of extended dryness, and as a result of awareness raising activities of a number of stakeholders. The implication of governing for drought in the context of flooding recovery is also discussed related to the flooding period of 2013-2014 discussed in Sects. 5.2 and 5.2.4. In Sect. 5.5 we conclude by exploring the potential meta-governance failures in the wider English water management system. In particular, we highlight the development of political 'silos' and fragmentation that were expressed in situ in Somerset in the aftermath of the flooding events. Policy and implementation silos exist between drought and flood in the definition of the target of adaptation efforts for a future of climate change. These silos need to be addressed in ongoing water management policy, and on the ground adaptation actions in the Somerset region if resiliency to future events is to be increased.

\subsection{National and Regional Climate Change, Water Management and Drought Governance Contexts}

\subsubsection{The Geo-Hydro Context of Somerset Water System and Future Climate Impacts}

The Somerset Levels and Moors is a unique manmade wetland landscape of international importance for nature and archaeology. A significant part of the low-lying Somerset Moors is designated as a Special Protection Area and a Ramsar site, which depend upon flooding. The area is also rich in archaeological sites that depend on waterlogged conditions for their preservation.

The steepness of the uplands, coupled with the geology and soil conditions, generates quick run-off from short intense rainfall. The upland areas of the wider catchment (Mendip, Blackdown and Quantock hills) are very steep, but the lowland areas of the Somerset Levels and Moors are very flat. This means that rainfall run-off 
travels very quickly down from the uplands but then slows down and pools in the Somerset Levels and Moors. The high-level embanked channels overflow and floodwater is stored in the Moors before it can reach the Estuary. In addition, the very shallow gradient on the Somerset Levels and Moors means that the area drains water away very slowly and relies on a complex network of pumped drainage channels. Tide locking is a particular feature of the Somerset Levels and Moors; the lower reaches of the rivers Tone and Parrett are tidal for some $30 \mathrm{~km}$ (18.6 miles) from the Severn Estuary. The capacity of these channels can be significantly reduced by high tidal conditions; in particular the Parrett as it has no tidal sluice or control structure.

Widespread flooding of the lowland moors happens regularly from the perched main rivers which run through them. The moors are protected by raised defences as are many of the small villages and communities. During the 2013/2014 fluvial floods, flood defences across the area protected over $200 \mathrm{~km}^{2}$ of land and over 3500 properties. However, large areas of land were still flooded for many weeks and these included 172 properties. Strategic infrastructure which included main roads and the rail network were affected badly and some small communities were cut off for many weeks.

Climate change increases both the risk of flooding and drought in Somerset. UK droughts are projected to be more severe and affect larger areas of the country over the next 100 years. Example studies include a publication in the journal Water Resources Management (Rahiz and New 2013) and a study by scientists from the European Commission's Joint Research Centre and Kessel University (2014). Climate change will also increase the potential for stronger rainfall events. The implications for flood risk, however, will vary widely from location to location depending on local climatic changes that are at present difficult to predict with confidence. Climate change may also result in changes to large-scale atmospheric circulation patterns like jet streams, which are harder for climate simulations to predict. Recent results with state-of-the-art climate models have raised the possibility that climate change may affect the jet stream more than scientists previously expected, making floods in the UK more likely. However, the uncertainty in these projections remains large. Flash flooding could also become more frequent as extreme rainfall events are consistently predicted to become more severe.

\subsubsection{Regulatory and Governance Context of English Water Management}

In 2008 the UK government ratified the Climate Change Act. One aspect of this piece of legislation ensures relevant public bodies put plans in place to adapt to climate change. This has involved a range of activities specifically focused on adapting to climate change such as the National Adaptation Programme, and the UK Climate Change Risk Assessment (e.g. HM Government 2013; Wade et al. 2013). For example, the UK government now has 'Adaptation Reporting Power' requiring a range of stakeholders and companies to provide detailed reports on the 
current and future predicted impacts of climate change on their organisations, and their proposals for adapting to climate change. Many of these programmes and policies have influenced climate change adaptation planning and implementation within water management settings in the UK and in Somerset. There have been a wide range of research papers and policy white papers in the water sector assessing the climate change impacts on the UK water sector (e.g. Defra 2013; Fenn and Wilby 2011; HM Government 2008, 2011, 2012, 201; Wade et al. 2013). Relatedly, the water industry in the UK has engaged with a range of activities related to climate change forecasting and adaptation plans as part of their water resource management plans (WRMPs are also part of the Water Framework DirectiveWFD_reporting requirements).

Water management in the UK reflects a complex, multilayered and multi-actor regulatory and governance system. Water resources are managed differently across country boundaries in the UK; therefore, the following description applies to England only. Defra (Department of Environment Food and Rural Affairs) has the overall responsibility for policy related to the water and sanitation sector (e.g. quality of drinking water and other waters, sewerage treatment and reservoir safety). Defra also ensures that the "legislative framework for water management is fit-for-purpose" (Environment Agency 2015a, p. 7). The executive body who has responsibility for environmental regulation (long-term planning for quality, water provision, climate change adaptation, WFD implementation) is the EA. Economic regulation of the water industry falls under OFWAT (Office of Water Services), and monitoring of drinking water quality is covered by the Drinking Water Inspectorate. Natural England (NE) is an executive non-departmental public body responsible to the Secretary of State for Environment Food and Rural Affairs with a remit to manage and adapt areas of natural significance, and to manage green farming schemes in England.

In Somerset, Irrigation Drainage Boards (IDBs) oversee district water level management (of the Levels and Moors), and they also work on water level management in order to reduce flood risk to property and people. The IDBs are co-defined as Risk Management Authorities within the Flood Water and Management Act of 2010 alongside the EA, local authorities and water companies (Association of Drainage Authorities, no date). Defra is responsible for the IDBs; however, they work closely with the EA and lead local flood authorities, and are funded by a range of beneficiaries only one of which is the government. The Somerset Drainage Board Consortium (SDBC) is responsible for managing water levels to protect people, the environment and property (SDBC 2014). The English drinking water and wastewater companies are privatised but are still regulated by, and have reporting responsibilities to, the governmental bodies identified aboveDefra, EA, OFWAT and the DWI (Water UK 2015).

Somerset County Council (SCC) is responsible for managing strategic local services in Somerset. With regards to water management, they have a role to play in emergency planning, consumer protection, town and country planning and local flood management. They also act as 'knowledge brokers' for climate change adaptation awareness raising and other activities. Finally, there are a range of NGO's (non-governmental organisations) and associated stakeholders who have 
fairly large stakes in taking forward adaptation planning for climate change and water management within the Somerset region. A lot of these groups' interests are reflective of the delicate balance between nature and agriculture in the region and include, for example, the Royal Society for the Protection of Birds (RSPB), Farming and Wildlife Environment Group, South West (FWAG, SW) and Somerset Wildlife Trust (SWT). In the context of this current project, FWAG SW, RSPB and SWT are sub-partners to the Somerset regional pilot.

\subsubsection{Drought Governance Context: Managing Water During Normal and Crisis Periods}

Given the complex physical and policy landscape for water management in England generally, and in the Somerset area more specifically, it is useful to reflect upon drought governance as it relates to management of drinking water, agricultural water, and water for nature and biodiversity. Drought is seen to both influence, and be influenced by, activities related to drinking water, agriculture and horticulture, industrial activity, infrastructure (e.g. energy provision), navigation, and environmental protection (fisheries, wetlands, wildlife and plants) (Environment Agency 2015a).

There are a range of planning activities to increase the resilience of the English water system to short and longer term changes as a result of climate change and increasing water demand, including actions specifically related to exceptional drought events. For example, water companies in the UK are required to consider both supply planning (such as new supply and transfer investments) and demand management (water efficiency activities, and temporary use bans to restrict household and business consumption during droughts) as a way to increase the resilience of the water system to social, technological and climatic change. Achieving a resilient supply and demand balance has been deemed necessary as drought and water scarcity (van Loon and van Lanen 2013) are historical features of the water system in the UK (Rahiz and New 2012; Taylor et al. 2009) and because climate change will increase the frequency of short-term periods of dryness and multi-year droughts (Environment Agency 2015a).

The other actions that ensure the UK water system is resilient to changes in climate are how water is managed during drought and water scarcity events. With regards to drought governance at the national level, there is an existing emergency management hierarchy of national, regional and local decision making around emerging periods of crisis. The drought management scheme that covers Somerset is the 'South West Drought Plan' (Environment Agency 2012a), supported by a national level drought framework, which was updated in June of 2015 (Environment Agency 2012b, 2015a). The 2010-2012 drought also led to a recognition of the need to strengthen the networks that need to be mobilised during drought events (e.g. Lever 2012; Waterwise 2013). In 2012 a continually functioning national drought group was set up involving stakeholders from NE, NFU (National Farmers Union), 
Water UK, water companies, RSPB and many other organisations to address this issue.

The development of a new national level drought plan in 2015 is significant for the governance assessment, which will be presented in Sect. 5.4. For example, when we visited the region in 2013 a number of stakeholders indicated that there was a lack of clarity in the way problems were defined and goals related to drought were set, as well as lack of clarity over how particular drought strategies and processes are implemented, and by whom. This created a sense of fragmentation of roles and responsibilities of regional responses to drought within the Somerset region.

The EA report "Drought response: our framework for England" (Environment Agency 2015a) provides a better outline of the responsibilities for managing water resources during periods of drought. The main organisations responsible during a drought include

- "the EA; provides strategic oversight and responsible for monitoring, reporting, advising and acting to reduce the impact of a drought on the environment and water users

- water companies; responsible for managing water supply for their customers and taking a range of measures to maintain supplies whilst minimising environmental impact

- government; responsible for policies relating to water resources.

A number of other organisations and groups also play an important part in managing drought, including NE, Canal and River Trust, local councils and representative bodies such as National Farmers' Union (NFU), UK Irrigation Association and environmental charities. All those involved in dealing with the effects of drought plan their activities in case a drought occurs and ensure that the responsibilities of different parties are clearly defined and understood". (Environment Agency 2015a, p. 6).

During a drought the EA carries out a range of actions at a variety of scales depending on the nature of the drought (Environment Agency 2015a). Drought incident teams decide on courses of action including a range of environmental, hydrological and social-economic indicators to categorise drought; assess short- and long-term forecasts of drought; convene strategic drought management groups relevant to the scale of drought (e.g. National Drought Group); act as rapporteur to a range of governmental actors, partners, water companies, stakeholders and the media; deal with drought orders and permit applications from water companies; implement environmental restrictions on abstraction licences; and provide clear advice to the government (Environment Agency 2015a).

With regards to other actors during droughts, the role of Defra is to work with the EA and water companies to maintain public water supplies and minimise damage to the environment (Environment Agency 2015a). Water companies should be prepared for periods of dry weather through a range of plans called 
Drought Plans. These Drought Plans include a range of actions during droughts including publicity campaigns, customer restrictions, drought permits and orders changing normal operations and abstractions. They must match the long-term strategic adaptation strategies outlined in their Water Resource Management Plans, and satisfy 'needs' of both the environment and various water users (Environment Agency 2015a). The role of local councils - as discussed aboveis more in regards to emergency management and contingency planning, and convening local resilience forums (Environment Agency 2015a). The role of NE during a drought period is to give advice regarding the influence of the drought on a range of 'nature indicators' including protected habitats and species. NE also has a role to play in providing advice to a range of stakeholders (industry, farming, local community, etc.) during a drought period (Environment Agency 2015a). As NE also manages a number of National Nature Reserves they also have responsibility for a range of actions to protect vulnerable species in these areas (e.g. drought monitoring, restricting access to vulnerable nature areas) (Environment Agency 2015a).

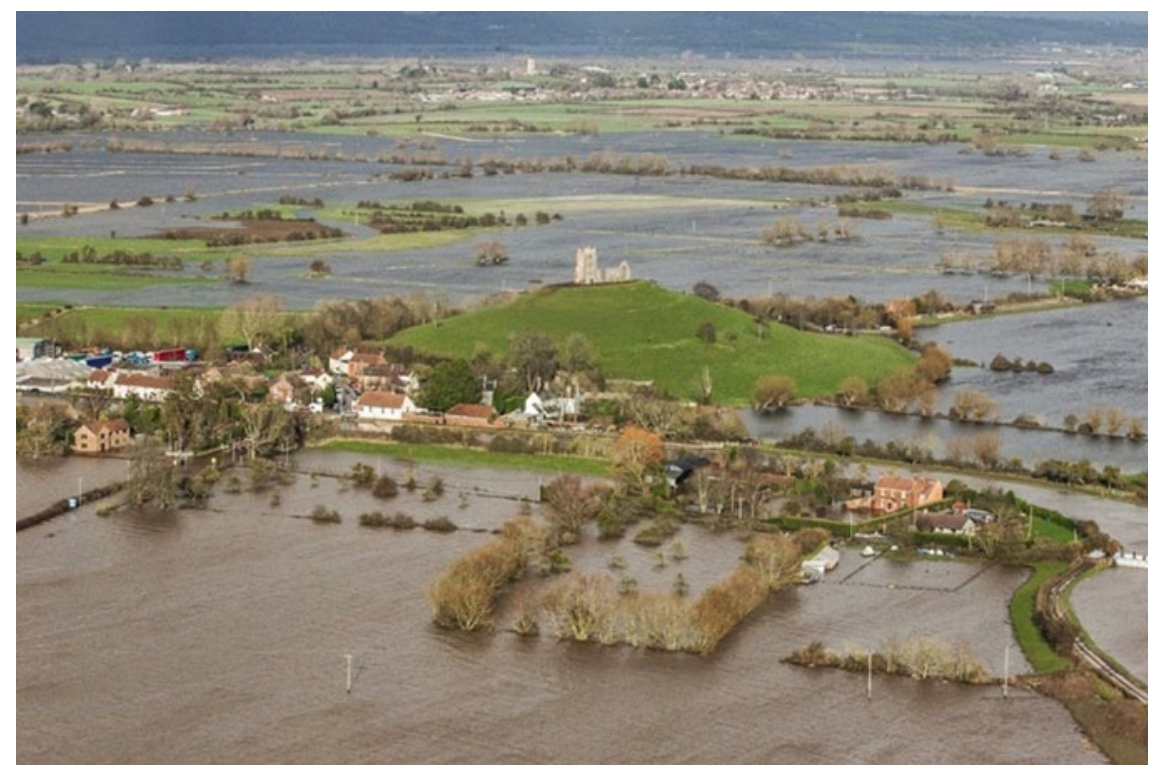

Fig. 5.2 Flooding in Somerset county in february 2014. We can see the St Michael Church on the hill isolated from the flooding territory (Somerset County Council) 


\subsubsection{Flood Policy Developments in Somerset Since the Floods of 2013/2014}

Although this book and project are focused on drought governance and resilience, the flooding events that occurred in Somerset across 2012-2014 have significantly influenced the long-term water management futures of the Somerset region. Thus, it is also useful to overview the developments to flood policy and how they have influenced adaptation actions towards drought and water scarcity governance.

The flooding in 2013-2014 included the flooding of the Parrett and the Tone catchments. It was the largest flood event known to have occurred in the region in the last 250 years with the army being deployed to assist during the crisis (BBC 2014; Environment Agency 2015b; see also Fig. 5.2). The floods became a hot political topic during the immediate crisis and recovery, with national and European media presence covering the contested and strongly debated causes, and solutions, to the problem. Thorne (2014) reflected how the 2013/2014 floods were socially divisive, with our own research during the period of flooding recovery highlighting the de-legitimisation of various stakeholders involved in water management throughout these public debates. It can be argued that the flood event obscured some options for recovery and future adaptation and entrenched others (Browne 2014; Butler and Walker-Springett 2015). The flood event also offered an opportunity for improving resilience, resistance and relations between the public, various regional stakeholders and other water practitioners (Butler and Walker-Springett 2015). The policy developments that emerged as a result of these flood events need to be viewed in the context of the divisive and contested nature of the flood recovery process, throughout which there was a series of social and political struggles to maintain a more or less balanced policy response.

The EA, whose funding and investment decisions are based on national assessment and cost benefit analysis, is currently the main provider of flood risk management activities. After the flood event of 2013/14, the 20 Year Flood Action Plan was developed to achieve a long-term vision for the area to reduce the extent and impact of flooding (Cameron 2014). The plan includes works being done to repair flood defences in the region, build new flood defences and enhance the capacity of various drains in the region to reduce the risk, depth and duration of any floods in the future (Environment Agency 2015b). It also identified dredging around the Levels and Moors to reduce flood risks (Environment Agency 2014), creating new banks, increasing pumping capacity and additional maintenance activities such as weed control (Environment Agency 2015b). The implementation of the 20 Year Flood Action Plan is being spearheaded by FWAG SW (a sub-partner on the DROP project).

The Somerset Rivers Authority (SRA) is a key part of the 20 Year Flood Action Plan. The SRA will bring together the Flood Risk Management Authorities (the EA, the Internal Drainage Boards, the Lead Local Flood Authority (SCC) and the other Somerset local authorities), to provide a strategic overview of the continued delivery of the Flood Action Plan, and to develop, agree and publish a Common 
Works Programme. It was set up to deliver greater local control and responsibility for maintaining and improving water and flood risk management on the Levels and Moors and across Somerset. The SRA will be a new body with its own Board, which will include representatives from each of the following partners: the five District Councils, SCC, the EA, the Parrett/Tone and Axe/Brue IDBs, the Wessex Regional Flood and Coastal Committee, and NE. Interim funding of $£ 2.7 \mathrm{~m}$ has been secured for the SRA for the 2015/16 financial year, the majority coming from Defra and DCLG (Department of Communities and Local Government). Local partners in Somerset, Defra and DCLG are working together to review options for a sustainable local funding solution for the work of the SRA from 2016/17 onwards.

\subsection{Drought Measures Taken Within Somerset in the Context of Flooding Recovery}

Concurrently to the 2013-14 floods, and the emergence of new policies and actions related to flood risk management, the regional partners on the DROP project (SCC, FWAG SW, SWT, RSPB) were developing a range of on-the-ground measures to enhance local resiliency to drought and water scarcity in the region. This section overviews the specific drought adaptation actions for agriculture and nature taken in the DROP project by the regional partners SCC and subcontractors FWAG SW, and SWT across 2013-2015.

\subsubsection{Agriculture and Drought Resilience}

The changing rainfall patterns under a changing climate are likely to have a profound effect on land management and farming in Somerset. This will result in additional demand for winter storage of water both to alleviate flooding and also to cope with reduced summer rainfall. Many farmers may need to consider irrigation from this winter storage, which could be anything from floodplain retention areas and creation of wetland habitats, to interception ponds, collection pits and butts. Farmers will need to implement water conservation measures and explore innovative approaches to water management on farms. In DROP, FWAG SW has helped farmers and landowners to adapt to these increasing extreme rainfall patterns.

As a county, Somerset has the greatest variety of soils in England. A soil risk assessment across the whole county to identify soils at risk of drought is missing and would be valuable in determining the actions required to make rural areas of the county more resilient to drought. FWAG SW has done a lot of work on Soil Risk Assessment for flooding and run-off. Within the DROP project they have altered 
this approach and criteria to do the same for drought. This provides valuable information and targeting for other measures identified within the project.

As previously discussed, in response to the 2014 Somerset Floods, FWAG SW has been involved in putting together a 20 Year Action Plan for water management in Somerset. This has included many of the Natural Flood Management and Soil Management measures that are included in the DROP Project. The Land Management aspects of the 20 Year Plan include a range of interventions like woodland planting, increasing soil organic matter, run-off attenuation features, improving soil structure and slowing watercourse flow that will improve drought resilience. This has constituted a major part of the progress achieved by the DROP Project in 2014.

Four sub-projects undertaken by FWAG SW as a sub-partner on the DROP project are related to improving the storage, conservation and recycling of water on farms; improving soil organic matter and soil structure; developing modelling and technology transfer for irrigation scheduling and water application management; and developing an Area Level Water Management scheme. The four projects are as follows:

(1) Working with farmers to investigate ways of storing, conserving and recycling water for on-farm use. This has involved implementing water efficiency measures and water conservation techniques in land-based businesses. Four 'demonstration' farms showcase various in situ soil protection measures, and open days have been held to encourage other farmers to implement these measures on their own land. Measures include (i) the reinstatement of ditches and drains to slow and elevate run-off on a historic rural estate in Somerset; (ii) use of temporary grassland to minimise soil erosion and installation of filter fences to prevent soil from washing into neighbouring properties; (iii) installation of a stone gabion and fencing feature to hold back fine soil that washes from the gently sloping arable field; and (iv) soil bunds to prevent soil washing through a hedge and a newly installed filter fence, silt pond, drains and established winter sown oats after maize at a local farm.

(2) Investigating ways of improving soil organic matter levels and soil structure. Different types of cover crop have been trialed on two pilot sites to help build organic matter. Healthy soil structure and high organic matter levels help to increase soil resilience against the effects of waterlogging and drying. This is especially important on arable farms where the normal sources of organic matter are in shorter supply due to the removal of biomass. Both sites are being monitored through a combination of infiltration measuring and earth worm counts.

(3) Developing modelling and technology transfer in the Upper Parrett catchment on irrigation scheduling and water application management. The Upper Parrett was chosen as a pilot area because water demands for agriculture here are high related to potato production. This study aimed to identify opportunities to improve the accuracy of irrigation scheduling to deliver potential savings during summer months within the Upper Parrett catchment when available resources are at greatest risk. In conjunction with 
potato producers Branston Ltd, and following installation of Dacom probes in the four fields in May 2014, Soil Moisture Deficits (SMD) have been monitored throughout the growing season to determine relative dryness within the soil profile and enable the growers to more accurately manage irrigation water applications. Early indications are that the Dacom probes have provided a more reliable guide of actual SMDs and enabled growers to make more informed decisions on actual SMDs rather than relying upon guideline figures and subjective visual assessment of soil dryness. A calculation of the financial value of the harvested crops will be completed in order to provide baseline data to assess the cost effectiveness of the different SMD monitoring techniques employed.

(4) An Area Water Level Management scheme for the East and West Waste area of the Somerset Levels and Moors developed in 2014. It assesses the current standards of water level management and watercourse conditions, and considers existing and future pressures from drought, as well as development and agriculture. A local contractor was employed (via the local Drainage Board) to carry out water level management works in the study area to reduce water loss and improve drought resilience.

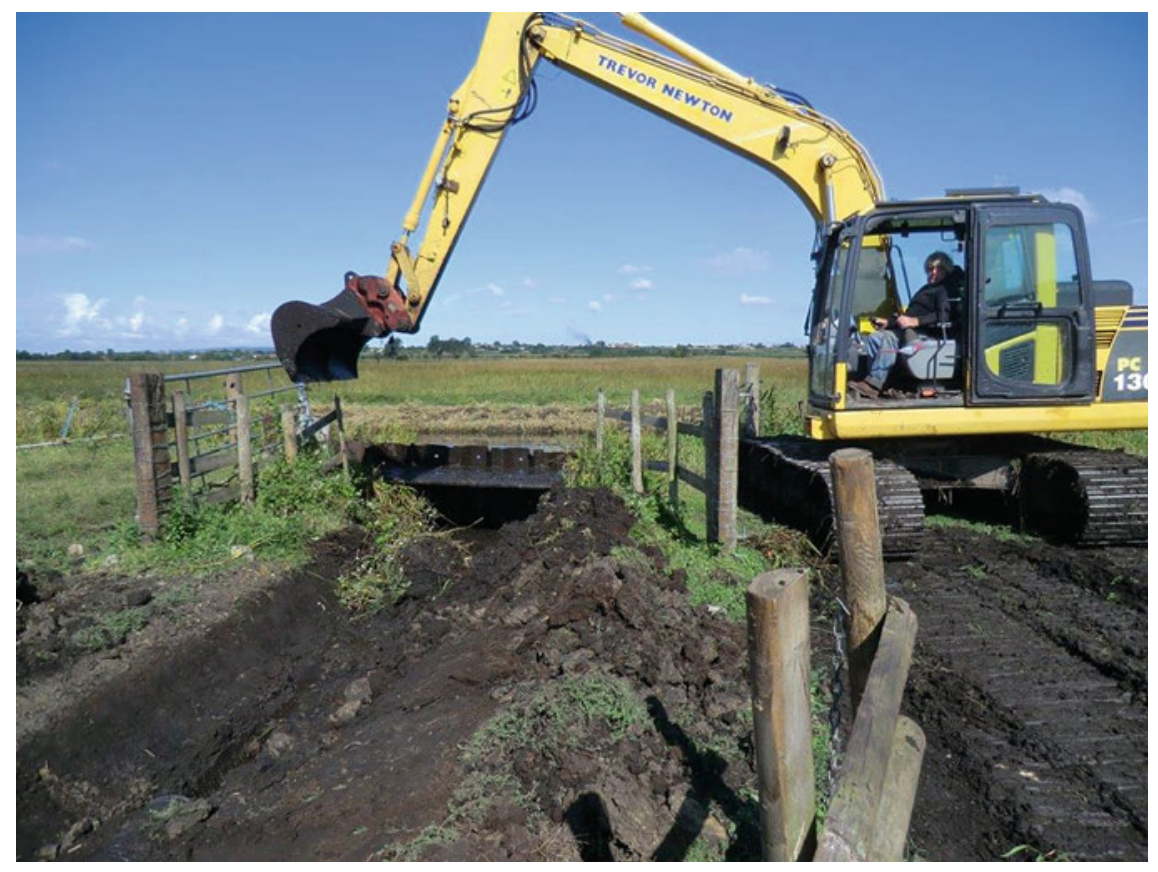

Fig. 5.3 RSPB site preparation for new sluice installation, West Sedgemoor, Somerset UK 


\subsubsection{Nature and Drought Resilience}

Other activities undertaken in Somerset during the DROP project have focused on land management advisory work that is connected to drought-proofing vulnerable areas, and capital investment in infrastructure to drought-proof key vulnerable areas on the peat moors and on the clay levels. This increases the ability to cope with drought conditions. Low-lying inland areas of Somerset depend on water management to maintain their environmental features and agricultural interests. Areas with exposed peat soils are particularly vulnerable to drought, which can damage peat soils, affect agricultural production and impact the natural and historic environment. Innovative landscape-scale approaches to water management will be used to plan and implement changes in water management for these areas.

As part of DROP, RSPB (through its subcontractor, SWT) has worked on nature reserves to make the most vulnerable habitats more drought resilient, restored habitats on nature reserves that contribute to drought resilience in the landscape and engaged with private landowners to pilot drought resilient restorations of peat extraction sites. Various water control structures were installed on West Sedgemoor RSPB reserves and SSSI between July and December 2014, including 9 culverts, 4 penstock flapvalves, 2 tilting weirs and the removal of 12 old structures (Fig. 5.3). The installation of these new structures is part of a programme of work

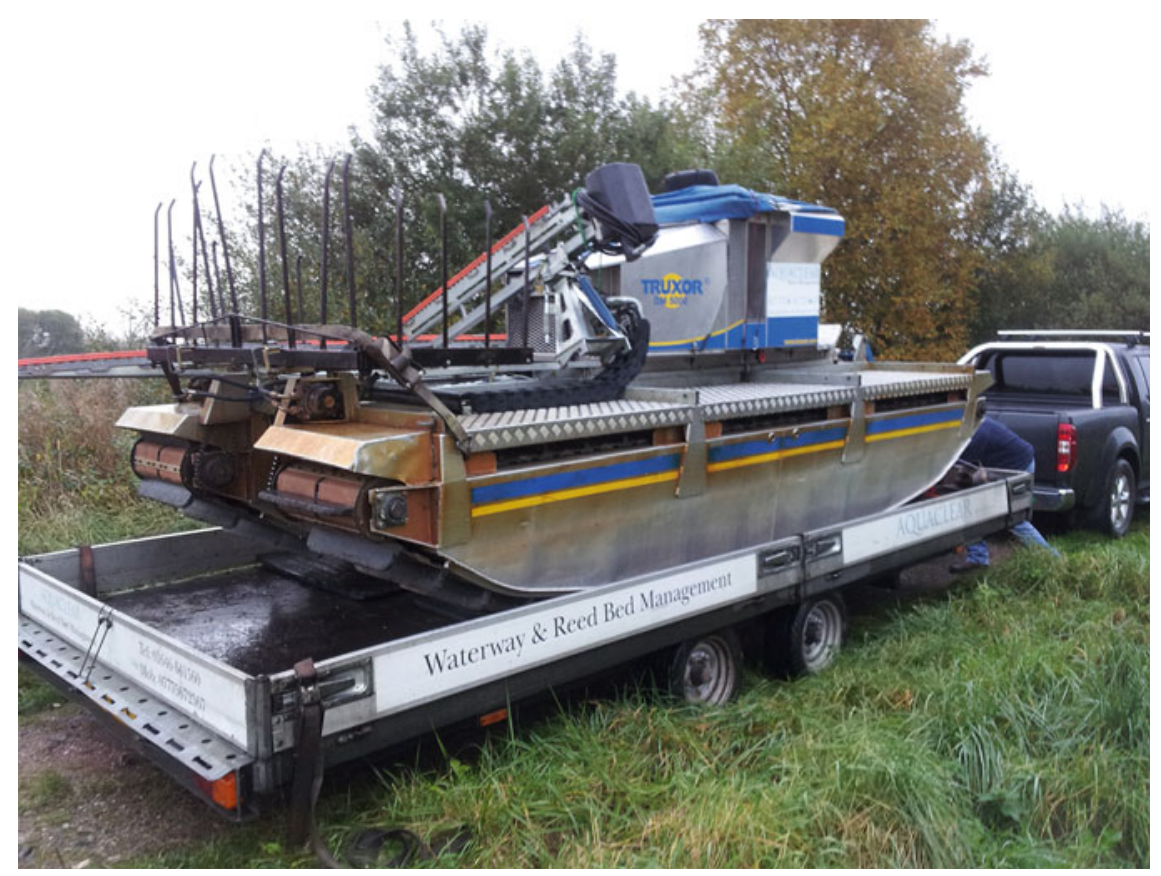

Fig. 5.4 Restoration of reed bed in Westhay Moor, Somerset, UK 
which improves efficiency and functionality of water management on this large wet grassland site to better cope with periods of both water shortage and water surplus, of which the DROP work is a significant part.

Until the Middle Ages large parts of the Brue Valley were covered in a peat-forming raised bog. In the UK the area of lowland raised bog is estimated to have diminished by around $94 \%$ largely through agricultural intensification, afforestation and commercial peat extraction. Future decline is most likely to be the result of the gradual desiccation of bogs damaged by a range of drainage activities and/or a general lowering of groundwater tables. In the Brue Valley the majority of the raised bog has been lost to peat extraction and agricultural intensification. The remaining fragments, which are now all within nature reserves, are raised above the surrounding peat voids and are consequently very difficult to keep wet. The largest remaining fragment of raised bog belongs to SWT, who have undertaken work to improve the habitat's resilience. Through the DROP project SWT has extended the programme of tree removal and scrub clearance; improved structures, fencing and gates to improve the grazing regime; and improved the ditch network and bunding to extend the areas SWT can deliver water to. A significant amount of restoration work has been carried out on the Westhay Moor raised mire habitat, including the clearance of 2 ha of scrub. A reed bed on this site was also restored by cutting channels and installing a structure to allow better water circulation (see Fig. 5.4). These actions will increase the drought resilience of both these habitats.

\subsection{Assessment of Drought Governance in Somerset}

Following the first visit to Somerset by the authors in 2013, we noticed several differences compared to many of the other case study regions presented in this book. There was much more awareness of climate change and its potential dual effects on water levels, with a wide range of stakeholders engaged in adaptation projects across the region. Our major reflections after this visit was that there was some fragmentation in how roles and responsibilities were defined, particularly related to initiating engagement and actions during drought periods. As discussed in Sect. 5.2 this may partially be resolved through the clearer responsibilities outlined in the new 2015 national drought response framework (Environment Agency 2015a).

However, the 'seismic shock' of the 2013/14 flooding altered the status quo for the discussions on water management. The politicisation of flooding in the region led to a reinterpretation of water management that became far more one-sided, with initial policy and practical measures focused largely on engineering type approaches such as dredging. Multiple stakeholders quickly called for the creation of more discharge capacity, a call that was magnified multiple times by the media and politicians. Although the Flood Action Plan was eventually developed-and the partners involved have pushed a more integrated, catchment management approach that will also increase resilience for drought and water scarcity - the lack of 
committed funds for fundamental aspects of this plan (such as to support the activities of the SRA) is problematic.

This section reflects briefly on the details of the governance assessment made as part of the DROP project by the authors, and reflects upon the four qualities of governance (extent, coherence, flexibility and intensity) underpinning drought adaptation within the region. As discussed in Chap. 3, (1) extent means that all elements are taken into account, (2) coherence means that elements of governance are more reinforcing and not contradictory of each other, (3) flexibility is that multiple roads to achieving goals are permitted and supported and (4) intensity occurs when the governance context urges changes and improvements in the status quo or current developments.

\subsubsection{Extent}

First, a high level of extent was observed in terms of stakeholders since their involvement in the management of drought in Somerset region was very strong and positive (cp. Sect. 5.2). The governance assessment revealed that the relationships that do exist around drought are largely positive and these relationships were also seen as having improved as a function of experience in the 2012 drought. The extent and nature of these stakeholder networks have been further clarified in the national drought framework released by the EA in June 2015 (Environment Agency 2015a). While the flood of 2013/14 was problematic and devastating for many, it can also be argued that it positively enhanced the range and scales of actors and networks involved in the issue of water management for the region, and the strategies and instruments that were being adopted to deal with water management particularly at the catchment level.

We found that there was a proactive anticipatory approach to drought management across water supply, nature and agriculture sectors in the Somerset region. This is reflected in the sorts of activities brokered by SCC and the sub-partners of the DROP project described in Sect. 5.3, and in the way that the partners involved in DROP have also been key actors in the 20 Year Flood Action Plan and SRA. Our assessment found that the types of strategies being suggested for increasing drought resilience were comprehensive for drinking water, but that a larger range of strategies for agriculture and nature specifically related to drought and water scarcity adaptation still need to be developed and implemented.

In terms of the future, a complex and changing fiscal context for spending on environmental issues such as climate change adaptation, water management and flooding (Committee on Climate Change Adaptation 2014), including ongoing reduction in overall funding of local authorities, EA and DEFRA may potentially restrict the adaptation activities possible within the system. For example, the 20 Year Flood Action Plan and the SRA (and other such related partnership activities for water management occurring in the region) will rely on financial 
partnership investment in order to access government funds for ongoing activities (Committee on Climate Change Adaptation 2014).

Despite this, the Somerset Water Management partnership did manage to get funding for a catchment management approach, via a successful funding bid from DEFRA's 'Catchment Partnership Fund' for the financial year 2015/16. This fund supports eligible organisations seeking to host a new or existing catchment partnership. FWAG SW was awarded $£ 11 \mathrm{~K}$ as a catchment partnership 'host'. The money is primarily to demonstrate to Defra that there is movement in the direction of a stakeholder-led catchment plan. This funding is not for delivery; it is to enable catchment partnerships to be formed (with the wide range of stakeholders interested in water management). A Working Group has been constituted to plan how to work with communities and stakeholders to investigate mutually beneficial solutions to problems faced by the catchment. The Somerset Water Management Partnership exists to promote a sustainable and integrated approach to water and land use management in Somerset's catchments wherever possible. It provides an over-arching, broad-based advisory and consultative forum in which all aspects of water management in Somerset's catchments can be discussed and consulted upon.

\subsubsection{Coherence}

Second, there was coherence in the different levels and scales of stakeholders involved in drought governance in the region, and a positive coherence across different actors. These include effective statutory relationships but other examples also exist of partnerships going beyond the regulatory remits to work together. This collaborative way of dealing with drought and water scarcity is increasing in importance. These relationships became clearer after the drought period of 2012. The coherence of the stakeholders involved in drought management (particularly during periods of crisis) was also further clarified in the 2015 national drought framework (Environment Agency 2015a). Furthermore, although the floods can be seen to have been socially and politically divisive, constructive activities such as the catchment management approaches suggested in the Flood Action Plan and the sorts of relationships being initiated at a catchment level to respond to these plans could also be leveraged to support future drought adaptation activities.

As a result of previous experiences of drought and water scarcity there was an acceptance that drought was a problem for the region. There were also fairly consistent definitions of the problem and the goals related to drought and water scarcity across the different stakeholders, including farmers, although this idea of drought as a problem became increasingly restrictive following the floods particularly for non-specialist, urban and regional publics. However, key actors that we interviewed following the floods still identified drought as a potential future problem for the region (although potentially secondary to flooding as a problem).

There is a potential incoherence between the strategies suggested for flooding, and those for water scarcity. There also seems to be a question about coherence in 
regards to the measures, strategies and instruments to deal with drought and water scarcity in the region. The sorts of approaches being suggested for flood recovery and resilience (e.g. in the Flood Action Plan) for example, could potentially include strategies that are also positive for drought resilience, yet the extent to which these perspectives are combined is unknown. The responsibilities and resources for coherent drought and water scarcity governance were also seen to be more restrictive and decreasing as a result of the attention being pulled towards the 'primary' issue of flooding in the region. Stakeholders' responsibilities and resources were being pulled towards this issue, rather than there being explicit policy development to support greater coherence between flooding and drought policy and action.

\subsubsection{Flexibility}

Third, in regards to flexibility a positive assessment was made of different actors and networks that were involved in drought adaptation in various ways. However, the flood experiences were observed to have eroded some of the legitimacy of the actors in the region (such as the EA). This assessment therefore moved from a positive sense of flexibility related to multiple actors involved to achieve drought resilience and adaptation, to one that was slightly more restrictive. Despite this there is still a fairly clear institutionally defined approach to the problem of drought management, and there is some flexibility within the goals (see Environment Agency 2015a). Some actors, however, suggested that there was a lack of clarity in the way problems were defined and goals were set, as well as how they are implemented into particular strategies and instruments for drought adaptation (discussed in part in Sect. 5.2).

For example, the definition of the problem of climate change adaptation as flood recovery and mitigation diminished the legitimacy with which lead actors could talk to other actors about drought and water scarcity management (e.g. the county council talking to farmers or citizens, the EA engaging stakeholders in continuous talk about drought in the context of flooding recovery). Therefore, framing climate change adaptation as recovery and mitigation from flooding reduced the flexibility with which actors could take the lead in pushing forward a water scarcity and drought adaptation agenda in the region in the period of flood recovery. The governance assessment made in 2013, however-reflecting on the period of drought experience in 2012 - did reveal that the lead strongly sits with a range of actors when dealing with drought management policy and processes (if there is an actual drought). The process of trigger points and responsibilities is clearly defined. However, there was one criticism that such a defined approach for what happens during a drought can lead to an inflexibility at a local level of the plans. The recent drought in 2012 provides some interesting examples of the lead shifting between actors for pragmatic and strategic reasons, particularly related to the communication of drought. This has been further clarified in the 2015 national drought framework. 
Table 5.1 Final assessment of governance context for drought in Somerset, UK after two field visits (and after Winter 2013/2014 floods)

\begin{tabular}{|c|c|c|c|c|}
\hline & \multicolumn{4}{|c|}{ Criteria } \\
\hline Dimensions & Extent & Coherence & Flexibility & Intensity \\
\hline Levels and Scales & $\begin{array}{l}\text { Positive and } \\
\text { Increasing }\end{array}$ & $\begin{array}{l}\text { Positive and } \\
\text { Increasing }\end{array}$ & $\begin{array}{l}\text { Neutral and } \\
\text { static } \\
\text { (was supportive but } \\
\text { has decreased post } \\
\text { floods) }\end{array}$ & $\begin{array}{l}\text { Neutral and } \\
\text { static } \\
\text { (was supportive but } \\
\text { has decreased post } \\
\text { floods) }\end{array}$ \\
\hline $\begin{array}{l}\text { Actors and } \\
\text { Networks }\end{array}$ & $\begin{array}{l}\text { Positive and } \\
\text { increasing } \\
\text { (increasing with other } \\
\text { forms of water mgt) }\end{array}$ & $\begin{array}{l}\text { Positive and } \\
\text { increasing } \\
\text { (increasing with actors } \\
\text { going beyond duties) }\end{array}$ & $\begin{array}{l}\text { Neutral and } \\
\text { static } \\
\text { (was increasing but } \\
\text { is now on hold post } \\
\text { floods) }\end{array}$ & $\begin{array}{l}\text { Neutral and } \\
\text { static } \\
\text { (was increasing but } \\
\text { is now on hold post } \\
\text { floods) }\end{array}$ \\
\hline $\begin{array}{l}\text { Problem } \\
\text { perspectives and } \\
\text { goal ambitions }\end{array}$ & $\begin{array}{l}\text { Restrictive and } \\
\text { static (was } \\
\text { supportive but has } \\
\text { now decreased } \\
\text { specifically for } \\
\text { drought mgt after } \\
\text { floods) }\end{array}$ & $\begin{array}{l}\text { Restrictive and } \\
\text { decreasing } \\
\text { (was supportive but } \\
\text { has now decreased } \\
\text { specifically for drought } \\
\text { mgt after floods) }\end{array}$ & $\begin{array}{l}\text { Restrictive } \\
\text { and } \\
\text { decreasing } \\
\text { (was neutral } \\
\text { assessment but is } \\
\text { now less flexible } \\
\text { after floods) }\end{array}$ & $\begin{array}{l}\text { Restrictive } \\
\text { and } \\
\text { decreasing } \\
\text { (was increasing in } \\
\text { intensity but has } \\
\text { now decreased } \\
\text { specifically for } \\
\text { drought mgt after } \\
\text { floods) }\end{array}$ \\
\hline $\begin{array}{l}\text { Strategies and } \\
\text { instruments }\end{array}$ & $\begin{array}{l}\text { Positive and } \\
\text { increasing }\end{array}$ & $\begin{array}{l}\text { Neutral } \\
\text { (many instruments but } \\
\text { implementation lacks } \\
\text { coherence) }\end{array}$ & $\begin{array}{l}\text { Positive and } \\
\text { increasing }\end{array}$ & $\begin{array}{l}\text { Positive but } \\
\text { static }\end{array}$ \\
\hline $\begin{array}{l}\text { Responsibilities } \\
\text { and resources }\end{array}$ & $\begin{array}{l}\text { Positive but } \\
\text { decreasing (after } \\
\text { floods) }\end{array}$ & $\begin{array}{l}\text { Restrictive and } \\
\text { decreasing } \\
\text { (after floods) }\end{array}$ & $\begin{array}{l}\text { Positive but } \\
\text { static }\end{array}$ & $\begin{array}{l}\text { Negative but } \\
\text { static }\end{array}$ \\
\hline
\end{tabular}

Key for Colours. Red: Restrictive Orange: Neutral Green: Supportive

\subsubsection{Intensity}

Finally, there is a strong sense of intensity for drought issues from all levels and scales in the region. The lead actors and networks consider drought management and water scarcity as part of their core business. This is both as a result of a 
regulatory environment that requires this (see Sect. 5.2), and an example of how actors are going beyond regulatory defined agendas to promote the issues across a range of stakeholders. There is a strong intensity seen in the use of instruments and measures, and a process of constant renewal of the plans for drought in the region. Where the intensity of the issue decreases is in the sharing of resources associated with the tasks of adaptation. It is likely that this disparity between the intensity of problem definition and actual resources will only increase in the face of the reduction of public funding under conditions of austerity of the current government. These issues of problem definition for drought need to be seen in a complementary way with that of flooding which is explored below in some more detail.

On the second visit after the floods these assessments were mostly 'flattened'. By this it is meant that the intensity with which certain levels or actors were pushing for change and management reform specifically for the issue of drought and water scarcity had been greatly decreased (and defined as neutral and static in Table 5.1). Where it became particularly problematic was in the problem definition and goal ambitions as a result of the experiences of the 2013/2014 drought. The catchment management approaches being suggested as a form of flood mitigation and adaptation may potentially include drought measures in terms of the definition of drought as a problem for the region. Even the ability of different actors and stakeholders to define drought as a problem for the region became very awkward politically and socially as a result of the floods.

Table (5.1) provides a summary of the final assessment of the governance context for drought and water scarcity as a result of the two visits, and reflects the change in direction for many of these criteria as a result of the 2013/2014 floods.

\subsection{Conclusions: Planning for Adaptation in the Context of Contested Material Water Histories and Meta-Governance Failures Within the Broader Water Sector}

The case study of Somerset shows how the material water histories of a regionand the ways in which these histories are governed through both emergency management and longer term planning processes - shape the directions of flood and drought adaptation. The Somerset case study is unique as it offers an opportunity to explore in situ the political contestation that can occur around water management and climate change adaptation, in particular, the siloing of policy areas, and the fragmentation of adaptation activities this can create.

In part this has to do with the way that the flooding events of 2013/14 played out in time. The Somerset flood event reflected a departure from the normal conceptualization of flooding as an extreme event, with a 'blame game' about the causes of the flooding and the extent of the impacts being initiated against a number of key governmental stakeholders (McEwen et al. 2014). Emergencies and extreme events 
reflect decisions that are both planned for (contingencies such as the National Drought Framework discussed in Sect. 5.3, or the UK Civil Contingencies register), and sets of decisions orchestrated at the time of an emergency or exceptional event (Adey and Anderson 2011). The form that the 'flood intervention' took during this period was highly politicised (McEwen et al. 2014), and reflected a militarization of emergency water management. This is partly to do with the unexpected scale and duration of the flood event. Also, as Gilbert (2012) states, such militarization of climate change events "perpetuates an externalised concept of nature that is to be commanded and controlled, with no real sense of ecological prioritization" (p. 10). The discussions following the floods were dominated by conversations of infrastructure and engineering solutions such as dredging as longer term adaptation options (Browne 2014). Catchment management for example - although promoted by WFD, Defra and in the Flood Action Plan for the region (Cameron 2014) - did not strongly feature in the development of formal policy in the region following the floods (Environment Agency 2015b). Lead stakeholders in the Flood Action Plan and SRA are, however, now promoting this agenda.

Recent research has shown that the winter floods increased British peoples' perspectives that climate change was happening in the UK (Capstick et al. 2015). It is a missed opportunity that such events were not used to encourage a public discussion about the potential extreme climate and water futures of both flooding and drought for the UK in public fora. A consequence of the policy outfall of this extreme event was a siloing of flooding from wider water management issues, partnerships, networks and adaptation activities already occurring in the region and which had harnessed a more complete sense of the connection of drought and flooding governance than that represented in the policies that emerged post the floods of 2013/14. Encouragingly, this recognition of the need to integrate flood and drought research, innovation, practice and policy development is now emerging in the industry (see for example Wharfe (2015) UK Water Partnership report).

What is important to reflect upon, however, is the way that the flood recovery and policy developments were framed, and how dealing with the flooding as an extreme event in this way closed down certain lines of discussion about how to connect water management adaptation activities in a more comprehensive way. Butler and Walker-Springett (2015) have reflected on the complexities of the ways floods are discussed within media and public fora, and how this obscures lived, private experiences which then shapes particular (restricted) policy and implementation activities. This is also reflective of other work on the social dimensions of flooding recovery (Medd and Marvin 2008; Whittle et al. 2011). Recovery from extreme events is often framed in terms of infrastructural recovery and adaptation; however, these are also missed opportunities to connect to a fuller understanding of infrastructural resilience (e.g. connecting across areas of water management and promoting climate change resilience more generally), and in creating greater community resilience (e.g. as discussed by Medd and Marvin 2008, 2014; Whittle et al. 2011, 2012).

Engagement with the critical literatures on water management in England highlights that the siloing of these water management areas in this way (especially 
during crisis) is not an unanticipated consequence of the existing water governance system. Both scarcity and flooding events in the UK continue to be framed as mismanagement and governance failures. This extends beyond the case study of Somerset and reflects the nature of water management in England. For example, drought events in England have historically been understood as a failure of planning and as such are seen as reflective of industry incompetence and a lack of planning (e.g. Hope 2012). The need for greater investment in supply and sewerage systems in order to create greater short and long-term resilience in the water industry was in fact a large part of the justification for the privatisation of the water industry in England (Bakker 2003, 2005; Maloney and Richardson 1994; Medd and Marvin 2008; Moss et al. 2008). Walker (2014) argues that the forms of water governance that have emerged from these conditions have actually created a (meta) governance failure when it comes to the governance of water scarcity across England (Walker 2014 drawing on Jessop 2000, 2003). The lasting legacies of these historical forms of governance-and the conceptualization(s) of resilience that they push forward and promote regarding infrastructures, nature and people - can be witnessed throughout the events narrated in this chapter.

The Somerset case study - which reflects upon the policy aftermath of a period of drought and flooding between 2010 and 2014-is an insight into how these (meta) governance failures affect multiple areas of water management across England. The fragmented nature of the English water sector splits multiple responsibilities for different aspects across multiple actors (and due to the nature of the Levels and Moors the water management in Somerset is particularly unique and complex). The assessment of the governance context in Somerset has shown that the long-term adaptation plans, and crisis management strategies and instruments that are emerging in each of these boundaries of responsibilities for water management are strong and becoming increasingly clear (e.g. Environment Agency 2015a). However, it is how they unfold in locations and times of crisis that actually reflect the entrenched meta-governance failures. Such emergency events often lead to calls to renationalize the water services in England (e.g. Clark 2012; Gaines 2013) — stemming from a range of critiques of the neoliberalization of water sectors internationally (e.g. Bakker 2013; de Gouvella and Scott 2012; Hall et al. 2013). However, this is the governance system that has been inherited, and that is still emerging (Walker 2014) in events such as those described in this chapter. The events in Somerset reflect a deeper political failure to maintain strategies and instruments that support water management both directions of climate change extremes (drought and flood), and a failure to dovetail adaptation into connected forms of policy and planning (such as land use planning).

A discussion of the types of solutions and actions that could proactively deal with both drought and flooding is needed, at all political levels. In the aftermath of the flooding it was difficult to see how such a measured debate could in fact be initiated-after all these were lives and livelihoods that were devastated by the flooding and many are still involved in the necessary long-term emotional and physical work implicated in recovery from such extremes events (Medd et al. 2014; Whittle et al. 2011). Discussing 'drought and water scarcity' at such times could be 
seen to be highly political and highly insensitive to the lived experiences of flooding recovery (Medd et al. 2014). After all, water is materially and socially a highly emotive subject-whether through its overabundance, its lack, or when polluted (Sultana 2011). As can be seen in the Somerset case, the use, control and conflicts around water shape peoples everyday experiences with water (Sultana 2011). Water in complex landscapes such as Somerset have substantial emotive aspects, as discussion of its control and use intersects with experiences of place, livelihoods, and social, economic, political and environmental futures. It is these futures that are directly being intervened with in both longer term planning (such as water resource management plans, drought plans), and emergency management and policies that emerge during and after periods of crisis. Whittle et al. (2012) have captured strongly the emotional work that occurs simultaneously to the practical work in restoring built and natural environments after a flooding event. Clearly then the discussion of the future of water scarcity for an area such as Somerset at a time when the whole region is concentrating on recovering from a period of water abundance is an emotive and contested conversation. Nonetheless, it is a fundamentally important one.

Despite these restrictions in this broader governance system, the pilot measures initiated by a number of stakeholders in the Somerset region (cp. Sect. 5.3) demonstrate a positive example of the sorts of water management activities that can bridge across the policy silos of flood and drought even in a period of 'disaster recovery'. Far from just satisfying certain WFD requirements for participation and catchment management, these initiatives reflect concrete attempts to change the experiences of stakeholders and engagements with the breadth of water management issues facing their region now and into the future. These are highly politicised and emotive processes - they tap into conversations about 'what the Somerset Levels and Moors are for'; highlighting conflicts between protection of people, agriculture and nature; and arguably reflect the ongoing entrenchment of neoliberal and meta-governance failures in relations to drought and water scarcity across England (Walker 2014). As Clout (2014) reflects, such conversations about the purpose of the Levels - whether to maintain agriculture or support nature conservation - are not new and they have probably been happening since the middle ages, when the area was first drained and developed.

Within this project and chapter, we can neither prescribe what the future of the Levels should be or what activities need to take place in order to continue opening up conversations about ways to bridge silos within water management activities within the region. However, we do call on leaders and stakeholders in the Somerset region to continue collaborative processes of water governance across the widest possible range of stakeholders. This will ensure that a diversity of views from these stakeholders are catalogued, when adaptation policies are developed across water policy domains. Hopefully, in this way broader meta-governance failures - which often entrench siloed 
conceptualizations of water systems resilience - can then be avoided. At a national level, there needs to be a greater consideration of the ways to overcome these meta-governance failures which is currently limiting the regional resilience of vulnerable rural and urban water catchments across England to future climate changes.

Open Access This chapter is distributed under the terms of the Creative Commons Attribution-NonCommercial 2.5 License (http://creativecommons.org/licenses/by-nc/2.5/), which permits any noncommercial use, duplication, adaptation, distribution, and reproduction in any medium or format, as long as you give appropriate credit to the original author(s) and the source, a link is provided to the Creative Commons license, and any changes made are indicated.

The images or other third party material in this chapter are included in the work's Creative Commons license, unless indicated otherwise in the credit line; if such material is not included in the work's Creative Commons license and the respective action is not permitted by statutory regulation, users will need to obtain permission from the license holder to duplicate, adapt, or reproduce the material.

\section{References}

Adey P, Anderson B (2011) Event and anticipation: UK Civil contingencies and the space-times of decision. Environ Plann A 43:2878-2899

Association of Drainage Authorities (ADA) (n.d.) An introduction to internal drain age boards (IDBs). Association of drainage authorities UK. http://www.ada.org.uk/downloads/ publications/IDBs-An-Introduction-web.pdf. Accessed 16 Dec 2015

Bakker KJ (2003) An uncooperative commodity. Privatizing water in England and Wales, 1st edn. Oxford University Press, New York

Bakker KJ (2005) Neoliberalizing nature? Market environmentalism in water supply in England and Wales. Ann Assoc Am Geogr 95(3):542-565

Bakker K (2013) Neoliberal versus postneoliberal water. Geographies of privatization and resistance. Ann Assoc Am Geogr 103(2):253-260

BBC (2014) Somerset flood crisis: how the story unfolded. http://www.bbc.co.uk/news/ukengland-somerset-26157538. Online 19 Mar 2014 ay 2012

Browne AL (2014) Fast water versus slow water. Fragmentation in adaptation and resilience to flooding and water scarcity. http://blog.policy.manchester.ac.uk/featured/2014/02/fast-waterversus-slow-water-fragmentation-in-adaptation-and-resilience-to-flooding-and-water-scarcity. Policy@Manchester Blog posted 14 Feb 2014

Browne AL, de Boer C, La Jeunesse I, Stein U (2015) Assessment of the governance context of drought and water scarcity policy for Somerset, UK. Final report application of the governance assessment tool for water scarcity and drought adaptation. The DROP Project, University of Manchester, UK

Butler C, Walker-Springett K (2015) People and politics in the aftermaths of floods. [Blog]. http:// geography.exeter.ac.uk/media/universityofexeter/schoolofgeography/winterfloods/documents/ Blog_2015.pdf. Accessed 30 Jul 2015

Cameron D (2014) The Somerset levels and moors flood action plan. A 20 year plan for a sustainable future "We cannot let this happen again". [13 Feb]. HM Government, UK. http://somersetnewsroom.files.wordpress.com/2014/03/20yearactionplanfull3.pdf. Accessed 21 Oct 2015

Capstick SB, Demski CC, Sposato RG, Pidgeon NF, Spence A, Corner AJ (2015) Public perception of climate change in Britain following the winter 2013/2014 flooding. Cardiff University, Cardiff. http://orca.cf.ac.uk/68062/. Accessed 21 Oct 2015 
Clark N (2012) Renationalise English water [released online 31st January 2012] http://www. theguardian.com/commentisfree/2012/jan/31/renationalise-english-water. Accessed $30 \mathrm{Jul}$ 2015

Clout H (2014) Reflections on the draining of the Somerset levels. Geogr J 180(4):338-341

Committee on Climate Change Adaptation (2014) Policy note. Flood and coastal erosion risk management spending [2014-01-21]. Adaptation sub-committee Secretariat. https://www. theccc.org.uk/wp-content/uploads/2014/01/2014-01-21-ASC-Policy-Note-flood-defencespending-FINAL.pdf. Accessed 22 Oct 2015

Defra (2013) Catchment based approach. Improving the quality of our water environment A policy framework to encourage the wider adoption of an integrated catchment based approach to improving the quality of our water environment [PB 13934]. Defra, UK. https://www.gov.uk/ government/uploads/system/uploads/attachment_data/file/204231/pb13934-waterenvironment-catchment-based-approach.pdf. Accessed 19 Oct 2015

De Gouvello B, Scott CA (2012) Has water privatization peaked? The future of public water governance. Water Inter 37(2):87-90

Environment Agency (2012a) South west drought plan. Environment Agency, Bristol, UK. https:// www.gov.uk/government/uploads/system/uploads/attachment_data/file/292773/ gesw0112bvyh-e-e.pdf. Accessed 19 Oct 2015

Environment Agency (2012b) Head office drought plan. Environment Agency, Bristol, UK. https://www.gov.uk/government/uploads/system/uploads/attachment_data/file/297211/ geho0112bway-e-e.pdf. Accessed 20 Oct 2015

Environment Agency (2014) Effectiveness of additional dredging: part of the 20 year flood action plan. Environment Agency, Bristol, UK. https://www.gov.uk/government/uploads/system/ uploads/attachment_data/file/392471/The_effectiveness_of_dredging_elsewhere.pdf. Accessed 19 Oct 2015

Environment Agency (2015a) Drought response: our framework for England. HM Government, UK. https://www.gov.uk/government/uploads/system/uploads/attachment_data/file/440728/ National_Drought_Framework.pdf. Accessed 28 Jul 2015

Environment Agency (2015b) Somerset levels and moors. Reducing the risk of flooding [notice version updated 14 January 2015]. HM Government, UK. https://www.gov.uk/government/ publications/somerset-levels-and-moors-reducing-the-risk-of-flooding/somerset-levels-andmoors-reducing-the-risk-of-flooding. Accessed 20 Oct 2015

Fenn C, Wilby R (2011) Smarter licensing to reduce damage abstraction from environmentally fragile rivers with minimum possible impact on water resource yield. River Itchen case study. Report. WWF-UK, London

Gaines M (2013) Rentationalising water industry should be a priority for Labour. Printed online 18 Jul 2013. http://wwtonline.co.uk/news/renationalising-water-industry-should-be-a-priority-forlabour\#.VboOEPIViko. Accessed 30 Jul 2015

Gilbert E (2012) The militarization of climate change. ACME. Int e-J Crit Geogr 11(1):1-14

HM Government (2008) Future water. The government's water strategy for England. Report Cm 7319, HM Government, London. https://www.gov.uk/government/uploads/system/uploads/ attachment_data/file/69346/pb13562-future-water-080204.pdf. Accessed 22 Oct 2015

HM Government (2011) Water for Life. Report CM 8230 presented to parliament by the secretary of state for environment food and rural affairs by command of her majesty, HM Government, London. http://www.official-documents.gov.uk/document/cm82/8230/8230.pdf. Accessed 20 Oct 2015

HM Government (2012) Draft water bill. Report CM 8375 presented to parliament by the secretary of state for environment food and rural affairs by command of her majesty, HM Government, London. http://www.official-documents.gov.uk/document/cm83/8375/8375.pdf. Accessed 20 Oct 2015

HM Government (2013) The national adaptation programme. Making the country resilient to a changing climate. Ref: PB13942. Report presented to parliament pursuant to Section 58 of the climate change act 2008, HM Government, UK. https://www.gov.uk/government/publications/ adapting-to-climate-change-national-adaptation-programme. Accessed 20 Oct 2015

Hall D, Lobina E, Terhorst P (2013) Re-municipalisation in the early twenty-first century. Water in France and energy in Germany International. Rev Appl Econ 27(2):193-214 
Hope C (2012) Thames water accused of 'mismanagement' by closing two dozen reservoirs. The telegraph, 30 Apr 2012. http://www.telegraph.co.uk/news/earth/drought/9236909/Thames-Wateraccused-of-mismanagement-by-closing-two-dozen-reservoirs.html. Accessed 30 Jul 2015

Jessop B (2000) Governance failure. In: Stoker G (ed) The new politics of British local governance. Macmillan, Basingstoke, pp 11-32

Jessop B (2003) Governance and meta-governance: On reflexivity requisite variety and requisite irony. In: Bang $\mathrm{H}$ (ed) Governance as social and political communication. Manchester University Press, Manchester, pp 101-116

Lever A-M (2012) Redefine concept of drought, environment agency urges. BBC science and environment. http://www.bbc.co.uk/news/science-environment-18150100. Accessed 22 May 2012

Maloney WA, Richardson J (1994) Water policy-making in England and Wales. Policy communities under pressure? Environ Polit 3(4):110-138

McEwen L, Jones O, Robertson I (2014) 'A glorious time?' Some reflections on flooding in the Somerset Levels. Geogr J 180(4):326-337

Medd W, Marvin S (2008) Making water work. Intermediating between regional strategy and local practice. Environ Plann D: Soc Space 26(2):280-299

Medd W, Deeming H, Walker G, Whittle R, Mort M, Twigger-Ross C, Walker M, Watson N, Kashefi E (2014) The flood recovery gap. A real-time study of local recovery following the floods of June 2007 in Hull, North East England. J Flood Risk Manag

Natural England (2013) National character area profile 142. Somerset levels and moors. file://C:/ Users/MBRXSAB8/Downloads/NE451.pdf. Accessed 29 Jul 2015

Natural England (2014) An assessment of the effects of the 2013-14 flooding on the wildlife and habitats of the Somerset levels and moors. Natural England, England. http://www.sanhs.org/ Documents/FloodingNE.pdf. Accessed 29 Jul 2015

Rahiz M, New M (2012) Spatial coherence of meteorological drought in the UK since 1914. Area 44(4):400-410

Rahiz M, New M (2013) 21st Century Drought Scenarios for the UK. Water Resour Manage 27 (4):1039-1061

Somerset Drainage Boards Consortium (SDBC) (2014) About us [webpage] http://www. somersetdrainageboards.gov.uk/about-us/. Accessed 14 Dec 2015

Sultana F (2011) Suffering for water suffering from water. Emotional geographies of resource access control and conflict. Geoforum 42:163-172

Taylor V, Chappells H, Medd W, Trentmann F (2009) Drought is normal. The socio-technical evolution of drought and water demand in England and Wales 1893-2006. J Hist Geogr 35 (3):568-591

Thorne C (2014) Geographies of flooding. Geogr J 180(4):297-309

van Loon AF, van Lanen HAJ (2013) Making the distinction between water scarcity and drought using an observation-modeling framework. Water Resour Res 49(3):1483-1502

Wade SD, Rance J, Reynard N (2013) The UK climate change risk assessment 2012: assessing the impacts on water resources to inform policy makers. Water Resour Manage 27:1085-1109

Walker G (2014) Water scarcity in England and Wales as a failure of (meta) governance. Water Altern 7(2):388-413

Water UK (2015) Price reviews. http://www.water.org.uk/price-reviews. Accessed 12 Dec 2015

Waterwise (2013) Water efficiency and drought communications report. Waterwise/Water UK/WWF-UK, London. http://www.waterwise.org.uk/data/2013_Waterwise_Drought_Report. pdf. Accessed 19 Oct 2015

Wharfe P (2015) Droughts and floods. Towards a more holistic approach. Releasing the full value of UK Research. UK Water Partnership, Research and Innovation Group, London. http://www. theukwaterpartnership.org/\#projects-and-publications. Accessed 20 Oct 2015

Whittle R, Walker M, Medd W (2011) Suitcases storyboards and newsround. Exploring impact and dissemination in Hull. Area 43(4):477-487

Whittle R, Walker M, Medd W, Mort M (2012) Flood of emotions. Emotional work and long-term disaster recovery. Emot Space Soc 5(1):60-69 